\title{
EOLÉTIOA química
}

\section{POTENTIOMETRIC QUANTIFICATION AND SPECIATION OF OXYGENATED GROUPS IN HUMIC SUBSTANCES USING BEST7 SOFTWARE}

\author{
Denise de Oliveira Vaz ${ }^{1}$, Andreia Neves Fernandes ${ }^{2,}$, Bruno Szpoganicz ${ }^{3}$, Maria Marta D. Sierra ${ }^{3}$ \\ ${ }^{1}$ Unidade de Serviços Tecnológicos; SENAI - Porto Alegre - Rio Grande do Sul-Brazil \\ ${ }^{2}$ Centro de Ciências Exatas e Tecnologia; UCS - Caxias do Sul-Rio Grande do Sul-Brazil \\ ${ }^{3}$ Departamento de Química; UFSC - Florianópolis - Santa Catarina - Brazil \\ *e-mail address: anfernandes@ucs.br
}

\begin{abstract}
In this study the BEST7 software was employed to quantify different classes of functional groups and to model the proton titration behavior of humic substances. To illustrate the process, the Suwannee River fulvic acid of the IHSS (International Humic Substances Society) was used. Five categories - two classes of phenolic groups (phenol and cathecol), two classes of carboxylic groups (benzoic and phtalic) and the combination between them (salicylic) - of oxygenated groups were considered as being responsible for the potentiometric behavior of the sample and were quantitatively determined. The most and the least abundant groups were cathecol $\left(3.300 \quad 0.010 \mathrm{mmol} \mathrm{g}^{-1}\right)$ and phenol $\left(1.2250 .070 \mathrm{mmol} \mathrm{g}^{-1}\right)$, respectively. The estimated equilibrium constants were also determined and were in good agreement with the literature values for phenol and cathecol groups and for benzoic, phtalic and salicylic acids. Distribution diagrams of the species were generated with the software SPE and SPEPLOT.
\end{abstract}

Keywords: Humic substances, potentiometry, BEST7 software.

\section{Introduction}

Humic substances (HS) are environmentally significant because they control the $\mathrm{pH}$ balance, mobility of contaminants, nutrient bioavailability, mineral weathering, aggregation, sedimentation and metal transport both in aquatic and terrestrial systems [1-3]. Even so, the nature, size, molar mass, conformation and aggregation processes of HS are still poorly understood. Most HS researchers uphold the theory that they are macromolecular structures because their apparent molar masses can exceed $1,000,000 \mathrm{~g} \mathrm{~mol}^{-1}$ [4-6]. In recent years, however, the idea of supramolecular associations of smaller HS molecules has been introduced [7, 8] and has been supported by direct analytical observations using dynamic light scattering or flow-field fractionation
[9]. In aqueous solutions, under certain $\mathrm{pH}$ and ionic strength conditions, HS have also been described as micelles or "pseudomicelles" [7, 10,11].

Humic and fulvic acids contain both polar and nonpolar substituents and can thus bind both hydrophobic and hydrophilic species [12]. The principal reactive groups in HS are the phenolic and carboxylic and their localization within the HS structures influences their reaction modes [13-15]. For example, two carboxylic groups alongside one another form a multidentate binding site for metals which gives rise to a much more stable complex than that formed by an isolated carboxylic group. Also, a carboxylic can be alongside a phenolic group, or two phenolic groups can be located side by side. These combinations generate different kinds of linkages or interactions [16]. 
One of the best techniques for analyzing functional groups in HS is potentiometric titration, because in this technique the HS are studied in solution, and the phenomena are therefore closer to those occurring under environmental conditions. However, due to the poorly defined titration curves generated, it is necessary to use programs to process the data in order to obtain the protonation constants and ligand concentrations [17]. The aim of this study is to develop a methodology using the software BEST7, SPE and SPEPLOT to quantify and to predict the speciation of reactive functional groups of any type of $\mathrm{HS}$, as a function of $\mathrm{pH}$. Instead of treating carboxylic and phenolic groups as independent sites, all the above cited possibilities of their localization and consequent interactions are considered. The respective dissociation constants as well as the distribution diagram of each species (speciation as a function of $\mathrm{pH}$ ) are also presented.

\section{Experimental}

\section{Reagents and Solutions}

The Suwannee River fulvic acid (SRFA) (IR101F) was purchased from the International Humic Substances Society (IHSS). The reagents were analytical grade and were used without further purification. Potassium chloride, calcium acetate and barium hydroxide were acquired from Synth. Potassium hydroxide was obtained from J.T. Baker. Potassium acid phthalate and hydrochloric acid were acquired from Merck. Buffer solutions ( $\mathrm{pH}=4$ and 7) were obtained from Carlo Erba Reagenti. All solutions were prepared with double-distilled, $\mathrm{CO}_{2}$-free water. Potassium chloride was used in all titrations to adjust the ionic strength $\left(\mathrm{m}=0.10 \mathrm{~mol} \mathrm{~L}^{-1}\right)$. Carbonate-free solutions of potassium hydroxide were used as the titration agent.

\section{Potentiometric Titrations}

Previous titration, solution of the potassium hydroxide was standardized by titration with potassium acid phthalate. Solutions of SRFA $(80.00$ $\mathrm{mg} \mathrm{L}^{-1}$ ) were prepared directly in the titration cell, dissolving the proper quantity of SRFA in water, adding $8.00 \mathrm{~mL}$ of $0.01 \mathrm{~mol} \mathrm{~L}^{-1}$ hydrochloric acid and completing the volume with double-distilled water to $50.00 \mathrm{~mL}$. The titrations were carried out in a thermostated $\left(25.00 \pm 0.05^{\circ} \mathrm{C}\right)$ sealed cell, in an inert

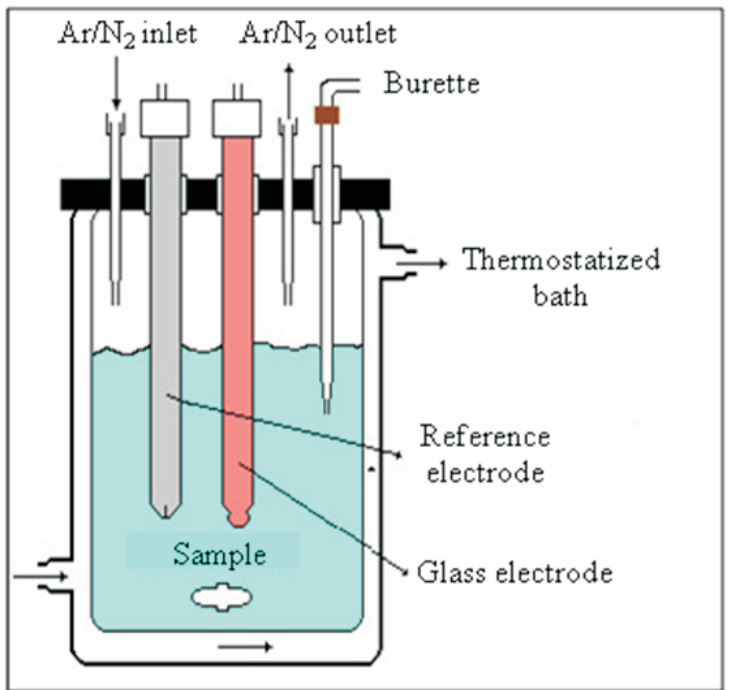

Figure 1. System utilized in potentiometric titration.

atmosphere (argon gas). The titration system is presented in Figure 1. All measurements were done starting $\mathrm{pH}$ to $c a .3 .0$ and in triplicate. Prior to the titrations the electrode was calibrated with dilute $0.01 \mathrm{~mol} \mathrm{~L}^{-1}$ of $\mathrm{HCl}$ to read directly $-\log \left[\mathrm{H}^{+}\right]$. The $\mathrm{pH}$ values of the titrations were read with a $\mathrm{pH}$ meter (Corning 350) equipped with glass and reference electrodes the latter filled with $4.00 \mathrm{~mol} \mathrm{~L}^{-1} \mathrm{KCl}$.

\section{The BEST7 Software}

The BEST7 software, which was employed to resolve the equilibrium data, is a Fortran program used for the determination of stability constants in simple or complex systems containing any number of interactions [17]. It treats the mass balance quantities, including the volume of titrate added, as known parameters, while the $\mathrm{pH}$ represents a measured dependent variable that reflects the set of equilibrium protonation constants that most accurately describes the system. Because of the generalized nature of the mass balance equation, BEST7 software can handle much more complex systems, such as those containing several ligands and many metal ions. The inputs for the BEST7 program consist of the total concentration of each component, the titration variables, the initial estimate of the equilibrium constant for each species present throughout the $\mathrm{pH}$ range, and the experimental profiles for $\mathrm{pH}$ versus base added. Unknown equilibrium constants can be estimated by 
comparison with values reported for systems with similar characteristics. The approximate amount of carboxylic acid and phenolic groups, in mmols, is previously determined by the Gran's function [18]. The software SPE and SPEPLOT were used to generate and plot the species diagrams. The computation was performed with the same mathematical algorithm employed in BEST7 [17].

A first approximation of the total analytical concentrations of oxygenated groups in the sample was obtained with the Schnitzer method [13-15, 19, 20]. Briefly, the method employs ion exchange reactions with $\mathrm{Ca}(\mathrm{OAc})_{2}$, to determine carboxylic acidity $(\mathrm{CA})$, and with $\mathrm{Ba}(\mathrm{OH})_{2}$, to determine total acidity (TA). The difference between these two values is then ascribed to phenolic acidity ( $\mathrm{PhA})$.

\section{Results and Discussion}

From the analytical data published on the IHSS webpage, the presence of nitrogen in SRFA is less than $2 \%$. In fact, no amide or other nitrogen group peaks are detected in its FTIR spectra. For this reason, only the oxygenated functional groups were included in this approach. Five categories of oxygenated groups were considered as being responsible for the potentiometric behavior of the sample: phenol, benzoic, cathecol, phtalic and salicylic. These functions simulate the HA and FA acidic properties with carboxylic and phenolic groups within a wide range of $\mathrm{pK}_{\mathrm{a}}$ values. To determine the concentrations and the potentiometric constants of these groups in SRFA, the input for the BEST7 program was a calculation matrix consisting of: $i$ ) the initial values of the protonation constants of each group - taken from the literature, for single molecules [21]; ii) the initial quantities of oxygenated groups - using the Schnitzer method $[19,20]$, the carboxylic, total and phenolic acidity values were, $4.90 \pm 0.11,11.50 \pm 0.50$ and $6.60 \pm 0.51 \mathrm{mmol} \mathrm{g}^{-1}$, respectively; iii) the volume and the molar concentration of the titration agent and, $i v$ ) the $\mathrm{pH}$ values measured after each addition.

Figures 2 and 3 show, respectively, a typical titration curve and the medium values of concentration found for the five sites considered. Oxygenated groups are homogeneously distributed with the most and the least abundant groups being, respectively, cathecol $\left(3.300 \pm 0.010 \mathrm{mmol} \mathrm{g}^{-1}\right)$ and phenol $(1.225 \pm 0.070$ mmol g $\left.\mathrm{g}^{-1}\right)$. The respective $\mathrm{pK}_{\mathrm{a}}$ values are shown in Table 1 and are in good agreement with those reported for single molecules [21]. Differences can be explained in terms of the polar effects of neighboring groups [22]. Hydrogen bonds between two acid groups, for example, can have a significant effect on the acidity of

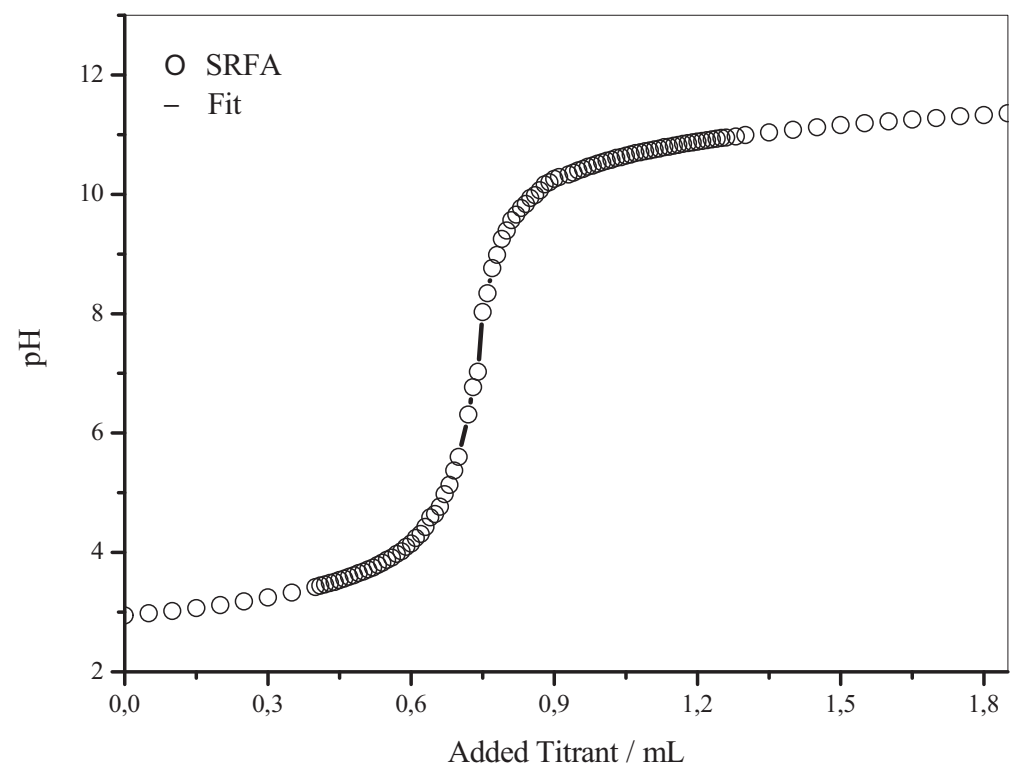

Figure 2. Typical potentiometric titration curve of the $80.00 \mathrm{mg} \mathrm{L}^{-1}$ solution of SRFA. Ionic strength $=0.10 \mathrm{~mol}$ $\mathrm{L}^{-1}$ with $\mathrm{KCl}, \mathrm{T}=25^{\circ} \mathrm{C}$. 


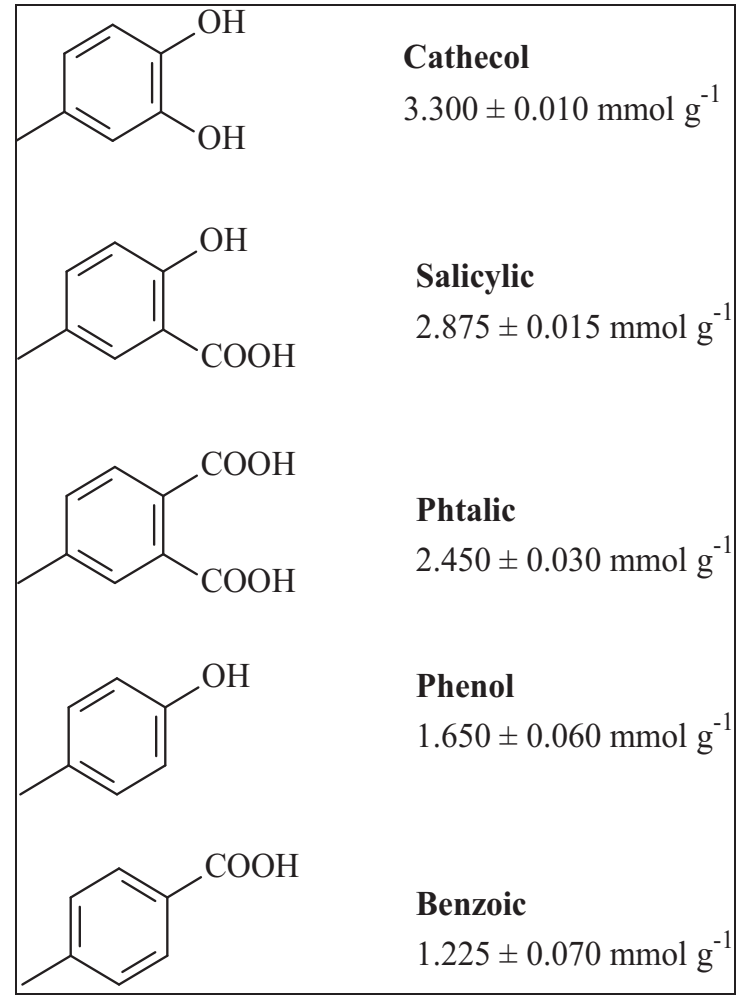

Figure 3. Chemical structures of the oxygenated groups considered and their corresponding concentrations in the SRFA sample, as determined with the BEST7 software. these groups by stabilizing the carboxylate anion. This stabilization may, in some case, increase the protonation constant values by around two units [23]. To fit the experimental and calculated data, the BEST7 program calculates the amount of each group and corrects their $\mathrm{pK}_{\mathrm{a}}$ values taking into account potential interactions among them.

In natural waters, in general, the $\mathrm{pH}$ values range between $\sim 5.0$ and $\sim 8.0$, going from fresh to sea waters, but can undergo drastic changes following environmental accidents. In principle, presenting groups with $\mathrm{pK}$ values between $\sim 3$ and $\sim 13$, the HS will buffer $\mathrm{pH}$ over a wide range in aquatic systems. However, in practice, their most effective buffering is between $\mathrm{pH} \sim 4$ and $\sim 7$, since that at higher $\mathrm{pH}$ values, the reactions of the carbonate system will nearly dominate.

In order to estimate the relative dominance of each group in the entire range of $\mathrm{pH}$ values, the SRFA distribution diagram was generated (Figure 4). From this it can be seen that for the phtalic $\left(\mathrm{H}_{2} \mathrm{D}\right)$, the salicylic $\left(\mathrm{H}_{2} \mathrm{E}\right)$ and the benzoic (HB) acids the deprotonation process begins at very low $\mathrm{pH}$. Above $\mathrm{pH} 5$ the protons associated to the carboxylic oxygen of these species are lost and the monoprotonated (HD and $\mathrm{HE}$ ) and/or deprotonated (B and $\mathrm{D})$ forms dominate. The cathecol group $\left(\mathrm{H}_{2} \mathrm{C}\right)$, on the other side, is mostly completely protonated all along the acid and neutral $\mathrm{pH}$ ranges. Its monoprotonated form prevails only above $\mathrm{pH} \sim 9$. The phenol group also

Table 1. Deprotonation data for the oxygenated groups in the SRFA sample.

\begin{tabular}{|c|c|c|c|}
\hline $\begin{array}{c}\text { Type of } \\
\text { deprotonation }\end{array}$ & $\begin{array}{l}\text { Equilibrium } \\
\text { Equations }^{\mathrm{a}}\end{array}$ & $\begin{array}{c}-\log \mathrm{K} \\
\text { (Literature values) }^{\mathrm{b}}\end{array}$ & $\begin{array}{c}-\log \mathrm{K} \\
\text { (Found values) }\end{array}$ \\
\hline Phenolic & {$[\mathbf{H}] \cdot[\mathbf{A}] /[\mathbf{H A}]$} & $9.82 \pm 0.04$ & $9.95 \pm 0.06$ \\
\hline Benzoic & {$[\mathrm{H}] \cdot[\mathrm{B}] /[\mathrm{HB}]$} & $4.00 \pm 0.01$ & $4.49 \pm 0.03$ \\
\hline First cathecol & {$[\mathrm{HC}] \cdot[\mathrm{H}] /\left[\mathrm{H}_{2} \mathrm{C}\right]$} & $9.24 \pm 0.04$ & $9.35 \pm 0.06$ \\
\hline Second cathecol & {$[\mathrm{H}] \cdot[\mathrm{C}] /[\mathrm{HC}]$} & $13.00 \pm 0.10$ & $13.13 \pm 0.07$ \\
\hline First phtalic & {$[\mathrm{HD}] .[\mathrm{H}] /\left[\mathrm{H}_{2} \mathrm{D}\right]$} & $2.75 \pm 0.02$ & $3.07 \pm 0.03$ \\
\hline Second phtalic & {$[\mathrm{H}] \cdot[\mathrm{D}] /[\mathrm{HD}]$} & $4.92 \pm 0.01$ & $5.47 \pm 0.05$ \\
\hline First salicylic & {$[\mathrm{HE}] \cdot[\mathrm{H}] /\left[\mathrm{H}_{2} \mathrm{E}\right]$} & $2.81 \pm 0.01$ & $2.95 \pm 0.03$ \\
\hline Second salicylic & {$[\mathrm{H}] \cdot[\mathrm{E}] /[\mathrm{HE}]$} & $13.40 \pm 0.00$ & $13.49 \pm 0.01$ \\
\hline
\end{tabular}

\footnotetext{
${ }^{\mathrm{a}}$ Abbreviations: HA: phenol; HB: benzoic acid; $\mathrm{H}_{2} \mathrm{C}$ : cathecol; $\mathrm{H}_{2} \mathrm{D}$ : phtalic acid and $\mathrm{H}_{2} \mathrm{E}$ : salicylic acid. A, B,
} $\mathrm{HC}, \mathrm{HD}$ and HE are the corresponding deprotonated species. ${ }^{\mathrm{b}}$ Martell and Motekaitis ${ }^{15}$. 


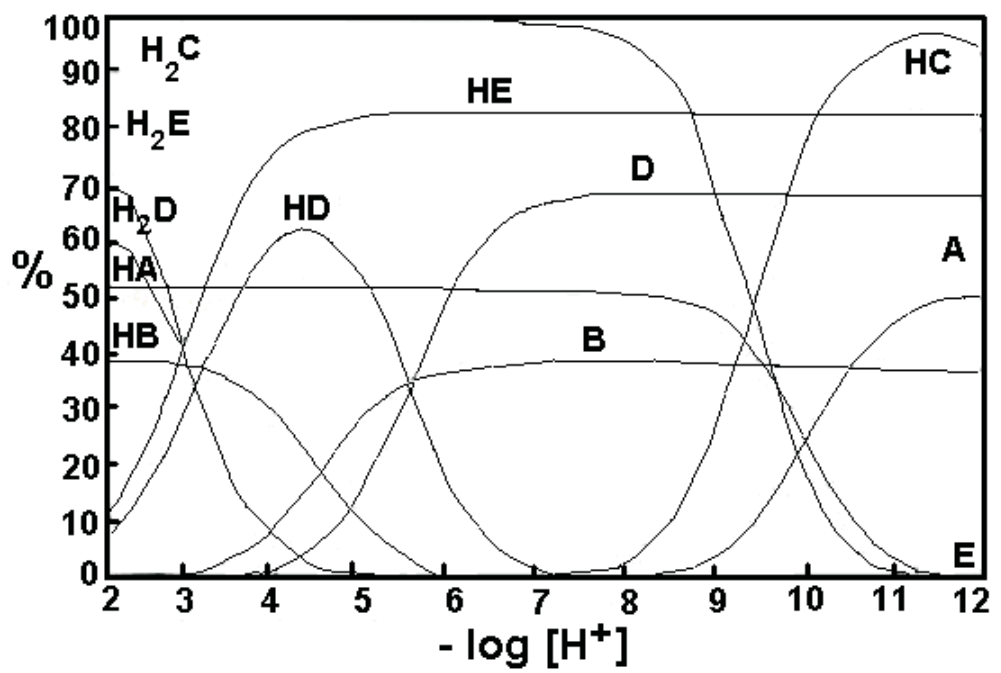

Figure 4. SRFA species distribution diagram as calculated by the SPE. Symbols have the same significance as in Table 1. Ionic strength $=0.10 \mathrm{~mol} \mathrm{~L}^{-1}(\mathrm{KCl}), \mathrm{T}=25^{\circ} \mathrm{C}$, SRFA concentration $=80.00 \mathrm{mg} \mathrm{L}^{-1}$

remains in its protonated form (HA) throughout the acid and neutral $\mathrm{pH}$ range, starting deprotonation only above $\mathrm{pH} \sim 8$. Therefore, under typical environmental $\mathrm{pH}$ conditions the oxygenated groups in FA might be predominantly in the chemical forms: protonated phenol (HA), deprotonated benzoic (B), protonated cathecol $\left(\mathrm{H}_{2} \mathrm{C}\right)$, monoprotonated phtalic (HD) and monoprotonated salicylic (HE, where only the hydroxyl group is protonated). At extremely low and/or high $\mathrm{pH}$ values the dominating species change, changing consequently their buffering capacity vis-à-vis eventual chemical perturbations.

\section{Conclusions}

Using the BEST7 program in the interpretation of the potentiometric titration curve it was possible to quantify (in mmol gi ${ }^{-1}$ ) the most reactive oxygenated functional groups of the fulvic acid, as well as determine their protonation constants. From this information it can be inferred that under typical environmental $\mathrm{pH}$ conditions the oxygenated groups in the studied fulvic acid sample might be predominantly in the chemical forms: protonated phenol, deprotonated benzoic, protonated cathecol, monoprotonated phtalic and monoprotonated salicylic (where only the hydroxyl group is protonated). The method was shown to be promising for acidity speciation of HS. This kind of information is critical to estimate the role of humic substances in the transport and fate of xenobiotics both, metallic and organic, in natural environments.

\section{Acknowlegments}

We are grateful to Conselho Nacional de Pesquisa e Desenvolvimento (CNPq, Brazil) for fellowships and Fundação de Ciência e Tecnologia de Santa Catarina (FAPESC, Santa Catarina) for financial support.

\section{References}

[1] D. L. Sparks, Geoderma 100 (2001) 303.

[2] G. de la Rosa, J. R. Peralta-Videa, J. L. GardeaTorresdey, J. Hazard. Mater. 97 (2003) 207.

[3] R. A. Alvarez-Puebla, C. Valenzuela-Calahorro, J. J. Garrido, Sci. Total Environ. 358 (2006) 243.[4] I. KögelKnauber, Org. Geochem. 31 (2000) 609.

[5] J. A. González-Pérez, F. J. González-Vila, G. Almendros, M. C. Zancada, O. Polvillo, F. Martín, J. Anal. Appl. Pyrolysis 68-69 (2003) 287.

[6] P. Faure, L. Schlepp, L. Mansuy-Huault, M. Elie, E. Jardé, M. Pelletier, J. Anal. Appl. Pyrolysis 75 (2006) 1.

[7] A. Piccolo, S. Nardi, G. Concheri, Chemosphere 33 (1996) 595.

[8] A. Cozzolino, P. Conte, A. Piccolo, Soil Biol. Biochem. $33(2001) 563$. 
[9] J. R. Lead, K. J. Wilkinson, E. Balnois, B. J. Cutak, C. K. Larive, S. Assemi, R. Beckett, Environ. Sci. Technol. 34 (2000) 3508.[10] C. S. Ragle, R. R. Engebretson, R. Von Wandruszka, Soil Sci. 162 (1997) 106.[11] M. M. D Sierra, T. G. Rauen, L. Tormen, N. A. Debacher, E. J. SorianoSierra, Water Res. 39 (2005) 3811.

[12] N. Calace, N. Cardellicchio, B. M. Petronio, M. Pietrantonio, M. Pietroletti, Mar. Environ. Res. 61 (2006) 40. [13] M. M. D. Sierra, K. Arend, A. N. Fernandes, M. Giovanela, B. Szpoganicz, Anal. Chim. Acta 445 (2001) 89.

[14] A. N. Fernandes, M. Giovanela, E. J. Soriano-Sierra, M. M. D. Sierra, J. Coast. Res. 39 (2006) 1062.

[15] A. N. Fernandes, C. Giacomelli, M. Giovanela, D. O. Vaz, B. Szpoganicz, M. M. D. Sierra, J. Braz. Chem. Soc.
20 (2009) 1715.[16] A. H. J Gillam, P. Riley, Anal. Chim. Acta 1982(141) 287.

[17] A. E Martell, R. J. Motekaitis, VCH Publishers: New York, 1992.

[18] G. Gran, Analyst 77 (1952) 661.

[19] M. Schnitzer, U. C. Gupta, Soil Scie. Soc. Am. 29 (1965) 274.

[20] M. M. D. Sierra, A. N. Fernandes, B. Szpoganicz, Talanta 62 (2004) 687.[21] A. E. Martell, R. M. Smith, R. J. Motekaitis, US Department of Commerce: Gaithesburg, 2004.[22] S. H. Sutheimer, M. J. Ferraco, S. E. Cabaniss, Anal. Chim. Acta 304 (1995) 187.

[23] J. A. Leenheer, R. L. Wershaw, M. M. Reddy, Environ. Sci. Technol. 29 (1995) 393. 